This item was submitted to Loughborough's Research Repository by the author.

Items in Figshare are protected by copyright, with all rights reserved, unless otherwise indicated.

\title{
When organization studies turns to societal problems: The contribution of Marxist grand theory
}

\section{PLEASE CITE THE PUBLISHED VERSION}

https://doi.org/10.1177/0170840615575948

\section{PUBLISHER}

(C) The authors. Published by SAGE Journals

\section{VERSION}

AM (Accepted Manuscript)

\section{PUBLISHER STATEMENT}

This work is made available according to the conditions of the Creative Commons Attribution-NonCommercialNoDerivatives 4.0 International (CC BY-NC-ND 4.0) licence. Full details of this licence are available at: https://creativecommons.org/licenses/by-nc-nd/4.0/

\section{LICENCE}

CC BY-NC-ND 4.0

\section{REPOSITORY RECORD}

Vidal, Matt, Paul Adler, and Rick Delbridge. 2019. "When Organization Studies Turns to Societal Problems: The Contribution of Marxist Grand Theory”. figshare. https://hdl.handle.net/2134/27588. 


\section{When organization studies turns to societal problems: The contribution of marxist grand theory ${ }^{1}$}

Matt Vidal, Paul Adler and Rick Delbridge

Forthcoming in Organization Studies.

${ }^{1}$ We thank Zlatko Bodrozic, Jason Heyes, Robin Holt, Jonas Ingvaldsen and Mike Reed for helpful feedback on an earlier draft of this paper. 


\section{Why marxist organization studies? Why now?}

We live in a time of crises, marked by financial collapses and extended recessions, rising economic insecurity and inequality, escalating ecological imbalances, and uncontrollable mutations in economic and political relations at both the local and the global level. Such conditions challenge social scientists to shift their focus away from their internal academic debates and towards the burning issues of the day. In doing so, scholars have made two discoveries. First, in such times of crisis, many previously taken-for-granted features of society are put into question. In particular, the efficiency of markets is challenged and capitalism no longer appears as the inevitable "end of history." Second, most of our pressing societal problems now appear to cut across the boundaries of the various social science disciplines that have been constructed over the past century or so.

These discoveries point to two new imperatives for the social sciences in general and for organization studies in particular. First, we need greater historical depth in our scholarship so as to understand better the genesis of contemporary events and to differentiate more confidently between those events that portend radical changes and those that reflect mere adaptation. Of course, individual historical case studies and attention to the temporal dimension have been frequent features of organizational research; but we share the view of Rowlinson and colleagues (2014: 258) who recently observed: "Saying that time matters is not the same as saying history matters." Unless we grasp how the phenomena we observe today are shaped by long-term historical trends, and how events today may inflect those trends, we risk misinterpreting the processes currently unfolding.

Second, we need to renew the original interdisciplinary mandate of organization studies. If we want to understand the variety of forces - economic, political, institutional, cultural, psychological - that (re)shape social organization and human action, we need to revitalize ties with the disciplines that focus on those various forces. Organization studies itself was constituted as an interdisciplinary venture, combining sociology, psychology, economics, politics, and a dose of anthropology. However, recent decades have witnessed a retreat of organization studies from the wider engagement with these constituent disciplines. Publications in organization studies journals reference papers from contiguous disciplines ever less frequently (Augier et al. 2005; Adler 2009a). But the press of external events has prompted renewed calls for interdisciplinarity, arguing that complex societal problems are best addressed by integrating the results of multiple methods and approaches (Jessop and Sum 2001; Sayer 2001; Biagioli 2009; Brewer 2013; Delbridge 2014). Such interdisciplinary efforts in turn demand new theoretical resources for achieving coherent integration rather than mere agglomeration.

Faced with these imperatives, we believe marxism can play a critical role in ensuring a vibrant future for organization studies. First, marxism offers insight into both the broad sweep of human history and the dynamics of capitalist development. Second, marxism offers a powerful interdisciplinary approach, unpacking the social core of economic relations and thereby helping to supersede the Parsonian pact (Stark 2000; Vidal and Peck 2012) that purchased space for sociology at the cost of a 
sharp boundary separating it from economics. In contrast to the mainstream focus on middle-range theory, Marxism provides a grand theory, one that offers a robust platform for combining historical depth and interdisciplinary breadth. This Special Forum was therefore motivated by our sense that organization studies' efforts to address the challenges of our times will be considerably enhanced if its middlerange theories systematically engage marxist grand theory.

In this Introduction, we briefly elaborate on the idea of and need for grand theory in organization studies as a crucial resource for fruitful historical interdisciplinarity, and we propose that marxism is a particularly useful grand theory in our efforts to contextualize, develop and integrate diverse stands of middle-range organization studies. Second, we present the core ideas of marxism, including its theory of history and its theory of capitalism as a distinctive mode of production. There are, of course, numerous readings of Marx and many schools of marxism, from structural (Althusser 2001) to humanist (Lukacs 1971), determinist (Cohen 1978a) to autonomist (Negri 1989), economistic (Kliman 2012) to political (Brenner 1976; Wood 2003). Here we leave aside the differences among these to focus on what we see as the core assumptions and propositions of marxism.

In our presentation of marxism, we interweave summaries of the four articles in this Special Forum, using them to illustrate some key marxist concepts. These articles demonstrate the value of marxist ideas across a range of traditional and emerging topics in organization studies, including organizational learning and communities of practice (Ingvaldsen), knowledge work, teamwork and collaboration (Adler), social media and valorization (Böhm, Beverungen and Land) and organizational change, routines and path dependence (Maielli).

We also use the case of the 2007-8 financial crisis to illustrate our argument. The 2007-8 financial crisis, which began in the US and spread around the globe to Western and Eastern Europe, Asia, Latin America and parts of Africa (Guillén and Suárez 2010), is a prime example of the type of societal problem that calls out for historical and interdisciplinary analysis. We show how organization-theoretic analyses of the crisis - such as those by Fligstein and Goldstein (2010), Guillén and Suárez (2010) and Pozner, Stimmler and Hirsch (2010) - can be deepened and extended with marxist grand theory.

\section{The need for grand theory}

If the urgency of current societal problems is driving us towards more historical and interdisciplinary scholarship, we submit that such scholarship will in turn require the reaffirmation of grand theories so as to lend coherence to our research. Grand theories, properly constituted, are essential to the vitality of historical and interdisciplinary ventures because they provide a coherent set of problematics, categories and concepts with which to forge links across the various middle-range theories and the various disciplines.

Merton (1968: 5) defined middle-range theories as those that are "intermediate to the minor working hypotheses evolved in abundance during the day-by-day routine of research, and the all-inclusive speculations comprising a 
master conceptual scheme." Boudon (1991: 519, emphasis original) defended Merton's rejection of grand theory as "hopeless and quixotic" attempts "to determine the essential feature of all social structure" or discover a basic set of concepts "that would be sufficient to analyze all social phenomena." While it is easy to agree with the rejection of theories consisting of "all-inclusive speculations" and which purport to be "sufficient to analyze all social phenomenon," we propose that grand theory can be properly constructed to avoid these sins and legitimately operate as a master research program, one that is progressive in the sense defined by Lakatos (1980).

Our view is that grand theory and middle-range theories are complementary rather than mutually exclusive. By grand theory, we mean a unified theory that provides an analytical and narrative framework for systematically developing and connecting a set of middle-range theories. Building on Lakatos (1980), grand theory is progressive and legitimate when developed through the elaboration of middlerange theories that solve empirical puzzles while systematically defending and revising core assumptions and propositions in a way that expands and enriches the overarching theory, rather than restricting that theory via ad hoc stipulations. Progressive grand theories have the potential to inform and integrate both inductive and deductive positions.

Our endorsement of grand theory runs counter to the postmodern skepticism articulated by Lyotard (1984) and others who attribute many of the horrors of the Twentieth Century to popular and elite enthusiasm for grand theory 'metanarratives' in general, and for marxism in particular, tarred by association with the gulag. Postmodernists thus urge instead a focus on local, emic perspectives, which are said to be multiple and typically incommensurable.

Marxists have responded to this skepticism in two ways. Callinicos (1991) observed that postmodern skepticism is itself a metanarrative and has therefore no greater claim on validity than the position it criticizes. More substantively, Harvey (1990: 44, 111, 339) demonstrated that marxist theory not only recognizes the multiplicity of local perspectives but offers a compelling explanation of them. The appearance and experience of fragmentation, ephemerality and discontinuity which postmodernism sees as constitutive of social (dis)order -- are themselves better understood as the outcome of rounds of space-time compression generated by capitalist globalization. Marxism thus allows us to establish some critical perspective on the postmodern condition, rather than merely internalizing its debilitating skepticism (see also Jameson 1984).

\section{History, modes of production, technology and class}

Marxism begins with production, because people must produce in order to live and because productive activity is inherently collective (Marx and Engels [1846] 1996). Marx's theory of the longue durée in history (known as historical materialism) asserts that at this time scale, change is driven by two structural contradictionsone between the forces and relations of production and the other between the basic social classes. 
The forces of production consist of the means of production (physical technology and raw materials), organizational technique, and human skill. The relations of production are the relations of ownership and control over the means of production, which define a set of basic social classes: a small class of propertyowning elite, who appropriate surplus labor from a large class of propertyless direct producers. As we discuss below, in marxist theory classes are objective structures, and they interact in complex ways with non-class structures such as gender and race to produce subjective identities.

\section{Modes of production}

Marx's key concept in this longue durée is the mode of production, defined as the historically specific combination of forces and relations of production. History has seen a succession of four basic modes of production-primitive communism, slavery, feudalism, and capitalism - and the analysis of the internal dynamics of capitalism suggest that a fifth is possible in the future-communism. This succession is characterized by the cumulative development of the forces of production and by corresponding changes in relations of production and class structure: from the absence of class divisions in primitive society to structures of slave-master, serf-lord, worker-capitalist, and potentially beyond class divisions again under communism. Against caricatures suggesting an oversimplified theory of unilinear evolution, Marx was acutely aware of "variation and of staggered chronology" in the actual path of historical development (Martin 1976: 268; see also Wickham 2007).

At this level of abstraction, the core developmental process in history consists of the dynamic contradiction between the forces and relations of production. The productive forces have a tendency to develop over time in the direction of higher productivity. That is because, on the one hand, human beings have an incentive to adopt labour saving innovations, and on the other, no social class has a sustained interest in seeing productivity regress (Cohen 1978b; Callinicos 2009b). The class structure of each mode of production at first serves to promote the growth of the productive forces, as each dominant class develops productive capacity in order to extract ever-greater surplus from the producing class. Yet, the cumulative development of the forces of production eventually renders obsolete the existing relations of production. Attempts by the dominant classes to maintain the status quo increasingly fetter the effective use and further development of the productive forces, and this provokes intensified class conflict and delegitimizes the dominant class.

Illustration: Community and innovation. In his article in this Special Forum, Paul Adler's paper finds inspiration in this vast historical panorama to interpret changes under way today in the forms of community operative within firms. He notes that the theme of community has become increasingly prevalent in organization studies and in practitioner-oriented management literature through concepts such as informal organization, organizational trust, organic organizational 
form, organizational culture, social networks, social capital, clans, supplier partnerships, industrial districts, communities of practice, and open source communities. In this literature, community seems to be an essential, indeed increasingly important, precondition for innovation. He highlights the resulting paradox: the idea of community itself — insofar as it has any determinate contentalmost invariably harkens back to Tönnies' concept of pre-capitalist traditionalistic Gemeinschaft (community as such) and its contrast with capitalist Gesellschaft (modern, voluntary association), but Gemeinschaft's traditionalism makes it unsuited to innovation tasks.

The resolution of this paradox, Adler argues, lies in acknowledging that at the current level of development of the productive forces innovation requires a qualitatively different and historically novel form of community. Arguing theoretically and illustrating his points with case data from field research on a software services company, Adler argues that capitalist rationalization has largely destroyed pre-capitalist community in the labour process, but in parallel has led to the emergence this radically new type of community. He sees this new type emerging through a dialectical synthesis of Gemeinschaft and Gesellschaft - creating a type that he calls Genossenschaft, or collaborative. Marxism sees organizational technique and form as part of the forces of production, and Adler concludes, consistent with Marx's argument that any historical new mode of production emerges in the womb of the old, that collaborative community is a socio-technical transformation representing communism's emergence in the heart of capitalism.

\section{Base/superstructure and soft determinism}

The forces and relations of production together constitute the economic base of society, and on this base sits society's political/ideological superstructure. Marxism's account of both the relationship between forces and relations of production and the relationship between base and superstructure have been taken to imply indefensible determinism: in the first instance, technological determinism of the forces over the relations of production and, in the second, economic determinism of the base over the superstructure. That line of criticism again relies on a caricature. In neither case does the marxist account imply a mechanical determinism. Wright (1978) has explicated Marx's argument here as referring to a process of "structural limitation," in which the determining factors set limits on the range of forms that the determined factors can take.

This soft, structural-limitation form of determinism does not exclude reciprocal effects of the superstructure on the base, but posits that the overall path of history will be marked by asymmetry in this two-way causal interaction (Engels 2010). In the assessment of Cambridge historian W. G. Runciman (2007, p. 7), Marx's grand-theoretic proposition -- that "the strongest evolutionary force driving human history is economic rather than ideological or political and that classes ... are its agents" -- continues to animate a great deal of fruitful historical research. 
Illustration: Material bases of institutional logics implicated in the 20078 financial crisis. The base/superstructure model allows us to enrich our field's research on the role played by culture and institutional logics in the 2007-8 financial crisis. Fligstein and Goldstein (2010: 29) suggest that the "rational actor/financial model formed the dominant cultural-institutional infrastructure" in which government regulators "were embedded." Pozner et al. (2010: 189) add that the core assumptions of this ideology, including the assumption that new financial models were able to correctly price risk, were reinforced because the key actors constituted a dense network which worked to suppress disconfirming information and encourage heard-like behavior. Pozner et al. document a shift within the mortgage industry, under the hegemony of efficient market theory, from a "Main Street logic" in which mortgages were seen as "consumer loans geared at supporting the institution of homeownership," to a "Wall Street logic" in which mortgages were seen as investment instruments. Both studies, however, leave open the question of why efficient market theory was embraced by regulators in the late 1970s and the Wall Street logic by the industry in the late 1980s.

Marxism reminds us that hegemonic ideologies rise and fall along with material transformations in the economy. From the late 19th century to WWI, international financial markets thrived. While private and central bankers, led by London and New York, controlled the levers of financial power and successfully promoted laissez-faire ideology throughout the 1920s, after the Great Depression the bankers were discredited and a coalition of industrialists, labour leaders and state officials adopted a protectionist and Keynesian ideology, which was hegemonic through the 1930s to the crisis of Fordism in the 1970s (Helleiner 1994). Although bankers and others never flagged in their advocacy of the ideology of financial liberalization, it was only after a decade of stagnation in the 1970s that it began to achieve widespread acceptance. In response to the pressures emanating from the economic base - a stagnant real economy with an oversupply of physical capital (Foster and Magdoff 2009; Vidal 2013) - and reflecting the material conditions of the postfordist accumulation regime, neoliberal ideology included a range of new financial institutional logics such as the efficient market hypothesis, the shareholder value approach to corporate governance and the Wall Street approach to mortgage lending.

\section{Structure and agency}

The marxist thesis of a soft determinism in these causal interactions -- of forces with relations of production, and of base with superstructure -- is further nuanced in marxist theory, since it allows that the relative causal roles of structural factors and human agency varies depending on the level of aggregation. Schematically, we can differentiate three such levels.

Across the highest level, in the broad sweep of history, the productive forces exert powerful structural limitations on the relations of production. Capitalist relations of production were impossible with the low levels of surplus produced by 
the slave mode or the early centuries of the feudal mode; the democratic state was impossible under feudalism. Individual and collective agency will explain little at this level of aggregation.

At a less aggregated level of analysis, such as the comparative analysis of national production regimes, employment systems or state policies within a given period, considerable causal weight must be given to political and ideological factors and to the collective agency of social actors (Smith and Meiksins 1995; Delbridge et al. 2011). It is here, at this level of analysis, that Gramsci's ([1929-1935] 1999) theory of hegemony is fruitful in its balancing of structural determinism and human agency (Delbridge, 2007; Levy \& Egan, 2003). For Gramsci, hegemony operates at both the ideological level, in the form of a compelling narrative in which the interests of the dominant group are presented as the interests of all, and at the material level, in the form of the "concrete coordination of interests" between dominant and subordinate groups (e.g. the democratic vote, high wages). In this analysis "moral and political leadership" play a fundamental role in the development of ideology. Ideologies are particularly likely to "grip the masses" when based in some form of material (class) compromise, but once an ideology has become hegemonic-widely accepted-it becomes material force in its own right.

At the most disaggregated level, such as the use of a given technology in a given enterprise at a given point in time, individual and collective agency may well appear dominant (Adler and Borys 1989). The implementation of technology in local contexts - like the design of technologies themselves - is to a very large extent shaped by local social conditions and the choices of local actors (MacKenzie and Wajcman 1999). However, it is a fallacy of composition to conclude from this that technology's intrinsic developmental potentialities do not have an asymmetrically powerful effect on the developmental trajectory of social structure over the long term and over larger social aggregates.

Illustration: Structural hegemony and organizational lock-in at Fiat. In his article in this Special Forum, Giuliano Maielli shows the value of integrating the more structural and more agentic dimensions of hegemony. He applies a neoGramscian interpretation of the agency-structure interplay and distinguishes between 'structural hegemony' and 'hegemonic projects'. These concepts are complemented with a critical realist analysis of institutional complexity (Delbridge \& Edwards, 2013). Agency is thus conceived as embedded within, but distinct from, different institutional logics which shape action. Hegemonic projects are undertaken by a specific group of actors within a particular set of relationships while structural hegemony is informed by the underpinning structural, institutional and historical context. The paper analyses the forces that prevented Fiat from increasing its output-mix flexibility after 1970 in spite of expected and actual changes in the structure of demand. Maielli interprets Fiat's inability to achieve a better fit with the changing market as a case of organizational lock-in, and explains this lock-in as the result of a combination of structural hegemony and the hegemonic projects of specific actors. Senior management at Fiat was aware of forthcoming changes in the market and took steps towards changing the business model and acquiring new 
competences to improve its capacity to meet market demands for higher quality vehicles, that is they engaged in various hegemonic projects. But they failed to develop the dynamic capabilities needed to trigger the self-reinforcing mechanisms (increasing returns and economies of scale) required to break out of the old metaroutines and thus impact significantly on the wider structural hegemony. Selfreinforcing processes (both political and cognitive) led to the confirmation of old meta-routines for design selection (reflecting the internal propensity to prioritise manufacturability over innovation), hence preventing the emergence of new metaroutines needed to drive the product mix towards higher-price segments or greater product-mix flexibility.

\section{The capitalist mode of production}

Capitalism is a distinctive mode of production that emerges when the forces of production reach a level of sophistication where they can only be deployed effectively under a complex division of labour based on a market for wage labour. The corresponding relations of production are characterized by: private ownership of the means of production by the capitalist class; goods and services are exchanged as commodities in markets producing profits for capitalist enterprises; profits stem from the surplus-value extracted from workers who sell their labour-power to capitalists in exchange for a wage. We explicate these below.

\section{Commodities and their value}

The first sentence of Capital, Vol. 1 (Marx [1867] 1990) is a good place to start: in capitalist societies, Marx writes, wealth presents itself as an immense accumulation of commodities - that is, as products and services produced by labour for sale. The commodity has two aspects that are often in conflict (in a relation that Marx calls a "real contradiction"): on the one hand, it is a use-value, in that it can satisfy a need, and on the other, an exchange-value, in that it can be sold for money.

To the key question of how exchange-value is determined, the marxist answer is the labour theory of value, which asserts that the exchange-value of a product is determined by the socially necessary labour-time associated with that product's creation. Supply and demand conditions explain the fluctuation of prices around this center of gravity (Shaikh 1982; Marx [1867] 1990; Marx [1894] 1981). This theory stands as an extension of a long line of classical economists' reflections on value, and - notwithstanding its eclipse by neoclassical theory - it has been shown in recent research to be an excellent predictor of market prices (Shaikh and Tonak 1997). Despite the short-run effects of changing supply and demand conditions, in the long-run products with less direct and indirect labour content will consistently cost less than products with more labour content.

The pressure on firms to reduce direct labour time along with other production costs is a defining feature of capitalism. Regardless of the subjective preferences of individual capitalists and managers, competition in financial and product markets relentlessly pushes firms to reduce the labour-time invested in the 
production of their own output. To the extent that they surpass their competitors in this efforts, they may temporarily earn super-profits. But their competitors are under pressure to imitate them, and when they do, this reduces the average labourtime required to produce that commodity and its average price will fall.

\section{Profit}

Marx's value theory seeks to explain how profits are made from the production and sale of commodities, assuming that all goods exchange at their real value. The answer offered by mainstream economic theory is that (when markets are competitive) enterprise profits are merely the normal returns to the provision of a scarce resource in the form of capital equipment. At equilibrium, we are told, profits reflect the marginal productivity of capital. This theory, however, is logically untenable, even though mainstream economists continue to rely on it. When Samuelson and other leading proponents of this theory were challenged by marxistinspired economists at Cambridge University in the 1960s (Joan Robinson and Piero Sraffa), the former were forced to admit that their theory was bankrupt (Samuelson 1966; Cohen and Harcourt 2003). The reason is not hard to see: it is not possible to talk of the marginal productivity of capital unless the value of the various pieces of equipment that constitute that capital can be aggregated; the only way to aggregate these values is by using their prices; but these prices include the profits of the enterprises that produced that equipment; so the rate of profit cannot be deduced unless the profit rate is already known. (By contrast, there is little difficulty adding up hours of labour: even if they differ in skill level, that complication can be handled by using a complexity coefficient.)

If profits in competitive markets cannot be explained by capital's marginal productivity, they can, in contrast, be explained by the power of capitalists to extract surplus-labour from their employees. The account proceeds in two steps. First, we note that once workers are dispossessed of their land and of any means of supporting themselves other than by working for a wage, their labour-power appears on the labour market as if it were a commodity. (Polanyi's ([1944] 1968) increasingly influential analysis of the role of the state in establishing the market economy clearly owes a strong debt to Marx in this regard). Capitalists pay workers for the use of this labour-power on the same basis as they pay for any other commodity - at a wage rate that represents the socially necessary labour-time required for this commodity's production. In the case of labour-power, its exchangevalue is therefore simply the wage-level that corresponds to the prevailing standard of living of working-class families, augmented where appropriate by a factor representing the investment in further education and training.

The second step in the marxist theory of profits is based on the historical fact that workers at this relatively advanced level of development of the forces of production can produce the equivalent of their exchange-value in only a fraction of the working day. Marx called this fraction "necessary labour-time." Capitalists, however, have the power - through their ownership and control of society's means of production-to demand that workers work a full day in exchange for access to this wage. The threat of unemployment ensures that workers' accept this deal. 
Profits, then, arise most fundamentally from the difference between the value produced in the entire working day (say, eight hours' worth) and the value produced during the necessary labour-time required to pay their full wage (say, four hours). Marx calls this difference "surplus-value." We see here again how marxist theory offers an interdisciplinary perspective linking the sociology of class dispossession with the economics of prices and profits.

Illustration: Value, free labour and profit in the social media industry. In their article in this Special Forum, Böhm, Beverungen and Land use marxist value theory creatively to present a provocative argument that users of social media are performing unpaid labour that accounts for the profits of social media companies. Their article uses the example of Facebook, which was able to make annual revenues over $\$ 5$ billion in 2012 employing only 4,619 employees. Böhm et al.'s central argument is that the nearly one billion users of Facebook, even though not in a wage-relation with it, generate surplus value, which is managed and valorized by the company. Facebook, like other social media companies, exploit their users to produce an "audience commodity" - an audience that is available to advertisers and that can be analyzed statistically to allow advertisers to target the most profitable users. This argument affirms basic aspects of classical marxist value theory while challenging others. Facebook is able to capture such free labour at a distance, so to speak, without any employment relation, by locking users into the platform and creating an artificial scarcity of user data.

\section{The capitalist enterprise}

Within the enterprise, the transhistorical contradiction between forces and relations of production that was discussed above is played out in the contradictory imperatives that shape the two aspects of the production process -- of efficiency in the labour process that creates use-value, and profitability in the valorization process that creates exchange-value (Marx [1867] 1990). The labour process is the cooperative process of work; the valorization process is the contested extraction of surplus value from workers. While early labour-process theory (Braverman 1974) proposed that deskilling and the degradation of work are the basic, inherent tendencies of capitalism, subsequent scholarship has argued that Marx's account is better understood as explicating a dynamic contradiction between degradation and skill upgrading tendencies (Adler 2007). Alongside the deskilling tendency, Marx saw a process he called "socialization" taking place in the form of increasingly largescale cooperation and an increasingly educated workforce. 
Illustration: Productive socialization, the collective worker and explicit knowledge. In his article in this Special Forum, Jonas Ingvaldsen offers a critique of the "communities of practice" literature, leveraging Marx's periodization and his concept of socialization. The concept of community of practice grew out of anthropological research on handicraft apprenticeships (Lave \& Wenger 1991), but it has been increasingly adopted as a general theory of organizational learning. Ingvaldsen argues theoretically - and offers illustrations from his field research against the extrapolation of this model from handicraft to modern industry under capitalism. As the labour process is progressively socialized, individual work effort is subsumed into a broader "collective worker," whose interdependence is managed formally through the technical division of labour and whose efforts are leveraged with the conscious application of science and technology. In such settings, learning depends far more on explicit knowledge, on formal work organization and on learning processes orchestrated by managers and technologists, rather than on tacit knowledge and informal coordination by workers posited by communities of practice theory. This process of capitalist rationalization tends to erode traditional sources of craft and professional community, but it also enables the emergence of new types of skills - less craft and more technical and scientific - and new forms of organization within the collective worker.

\section{Classes}

While the basic class structure of capitalism creates a primordial split between this working class and the capitalist class, the class structure becomes differentiated by several factors. First, capitalism leaves room, although progressively less, for a 'traditional' middle-class of self-employed or small-scale and family enterprises. Second, capitalist development stimulates the emergence of new high-skill and professional categories and a broadening layer of middle-managers, who find themselves in contradictory class locations (Wright 1997 ).

Marxist theory does not assume that class position alone determines identities and subjective interests, but sees class interacting in complex ways with gender, race, nationality and so on in shaping these. Consistent with the orientation to soft determination discussed above, marxism encourage us to consider the different causal weights of these various dimensions of differentiation in shaping behavior and attitudes (Gimenez 2001) and to pay close attention to the material bases and economic significance of gender/race/nation ideologies. For instance, in Western economies over the early- to mid- $20^{\text {th }}$ century, class and gender relations combined to produce a dominant labour market model of male breadwinning and female homemaking (Hartmann 1979). As underling economic relations changed in the $20^{\text {th }}$ century, gender relations and ideologies changed. 


\section{Developmental tendencies}

Marxist theory identifies several key tendencies of capitalist economies, each of which can be mitigated by counter-tendencies. Some critics see this conceptual framing as a weakness of marxist theory, since the dialectical interplay of tendency and counter-tendency typically does not generate determinate empirical predictions in any specific context. Marxists respond by arguing that if the capitalist system's dynamics have this somewhat chaotic character, then a good theory is one that identifies broad patterns that render intelligible that local unpredictability. Let us review this dialectical interplay in the key dimensions of capitalist development.

First, as noted above, the forces of production tend to develop over time through a process Marx called socialization. This socialization operates at three levels: increasingly large-scale cooperation within and between enterprises; an increasingly educated and technically sophisticated working class able to access and deploy society's accumulated scientific and technological knowledge; and increasing interdependence of increasingly specialized branches of economic activity across an increasingly integrated global economy (Adler 2009b; Marx [1867] 1990: 772, 1024). This socialization tendency is simultaneously stimulated and undermined by valorization pressures. Valorization, on the one hand, pushes firms to develop these new forms of cooperation, but on the other hand, acts as a centrifugal force when competition undermines cooperation.

Second, in relations among capitalists, market competition leads over time to its opposite-twin tendencies toward the concentration of capital into the hands of a small number of capitalists and firms, and centralization of capital in ever bigger enterprises. It is in the nature of the system that the big fish eat the little fish. Competition persists, however, both among the big fish and in driving the emergence of new entrepreneurial ventures.

Third, there is a persistent downward pressure on the rate of profit, leading to periodic crises of profitability. Capitalists seek to compete by lowering their costs; one of the key means of reducing costs is substituting machines for labour; but eliminating labor eliminates in the process opportunities for surplus-labour extraction; as a result, competition tends to drive down profit rates. While many have been skeptical of this tendency because it derives from the labour theory of value, there is robust evidence of declining corporate profit rates across the OECD beginning after the Second World War (Duménil and Lévy 2004; Glyn et al. 2007; Vidal 2013), thus vindicating core marxist concept. On the other hand, however, this process can be reversed if the cost of machines can be reduced fast enough. A second countervailing factor is the expansion of the capitalist system to previously non-capitalist regions and countries, opening up new sources of cheaper labour and new markets for firms' products (Wallerstein 1979).

This latter process contributes to the persistence of imperialist expansion in the capitalist world. Prior modes of production were also characterized by imperialistic expansion, but in those settings the drive was at root political and military. In contrast, under capitalism, imperialist expansion is driven by a 
convergence and entanglement of geopolitical and economic interests (Callinicos 2009a). The same relentless pressure for growth drives capitalist industry towards privatizing the various "commons" that have persisted within capitalist societies, turning the results and preconditions of communal activities into private property that can be absorbed into the process of capital accumulation.

Fourth, these basic features of capitalism generate periodic crises of overaccumulation. Any system of market-based commodity production must suffer the consequences of the lack of ex ante planning, and in a system based on competition for profitable growth, the key result is a persistent tendency to overaccumulation. Competition among firms-fueled by credit-drives a headlong rush of each firm to expand output faster than competitors. The result is predictable: periodic crises of overaccumulation in which capital is devalued, capacity destroyed and unemployment increased through bankruptcies, mergers and acquisitions. The countervailing process is devalorization: crises lead to the destruction of value, which sets the stage for renewed profitability (since the denominator of the rate of profit is reduced) and thereby prompts a new phase of accumulation. As Harvey (2010) has noted, such crises swept across the globe in 1848, 1929, 1973 and 2008-but we are still waiting for this latest one to devalue enough capital to relaunch capitalist growth.

Fifth, the capitalist system's growth imperative eventually bumps into the limits of the natural world. Marx presciently argued that capitalist agriculture created a metabolic rift between humans and the soil, as capitalism was unable to maintain sufficient recycling of soil nutrients (Foster 1999). The rift is most developed today in terms of the carbon cycle, which has been ruptured by the accumulation of $\mathrm{CO}_{2}$ in the atmosphere, overwhelming the capacity of natural sinks to absorb the additional carbon produced under capitalist production (Foster et al. 2011). In this instance, it is less clear that capitalism generates its own countervailing process. As Klein (2014) has argued, it seems most likely that this development tendency of capitalism can only be blocked by a radical socialist transformation.

Illustration: Concentration, centralization and socialization underlying the 2007-8 financial crisis. Although not framed in marxist terms, the concentration and centralization of capital are central to the organization theoretic accounts of Guillén and Suárez (2010), Pozner et al. (2010: 192) and Fligstein and Goldstein (2010: 31). The latter note that by the outset of the crisis "in every facet" of the mortgage-backed security industry - originators, packagers, wholesalers, servicers, ratings agencies - "five firms controlled at least $40 \%$ of the market (and in some cases closer to 90\%)." Guillén and Suárez (2010) emphasize the rise of giant, diversified and decentralized multinationals, both inside and outside of the financial sector, developing their analysis using Perrow's (1984) theory of normal accidents. This theory holds that the likelihood of catastrophe is high in any system were two conditions obtain: high complexity (i.e. many interdependent parts) and tight coupling (i.e. no slack or buffers in the system connecting the parts). Within the US financial system in the late 1990s, complexity increased due to the rise of giant, 
diversified, decentralized, globalized financial institutions. This reduced the ability of observers to understand the whole system. Coupling was tightened in the US financial sector by use of leverage (reducing buffers against wrong bets) and overthe-counter securities and derivatives that were tailor-made (hence difficult to exit), increasing the likelihood that single mishaps would have ripple effects. Coupling was tightened globally due to the growth of deeply integrated, lean global supply chains (which eliminate supply buffers) so that when financial disruptions bled into the productive economy they rapidly spread across the global economy.

Marxist theory enriches this analysis by locating the processes of increasing complexity and tight coupling within the deeper contradiction between productive socialization and private ownership. Although high complexity and tight coupling may increase system fragility on their own, in the financial crisis this potential fragility was turned into actual calamity by powerful actors operating according to the profit imperative within a system of private property. In terms of socialization, new financial instruments and tighter inter-firm linkages due to the concentration and centralization of capital brought new efficiencies to both the real economy and the financial markets. Yet, as Perrow (2010, p. 308) acknowledged, the collapse of the financial system was not spontaneous, but was driven by financial actors who actively used free market ideology "for personal and class ends with knowledge of the damage they might cause." Perrow shows that there were ample warnings of increased system risk associated with deregulation, which came from European regulators and a range of dissenting voices from the US Senate, House, Commodity Futures Trading Commission and the Federal Reserve Bank as well as from the hedge fund industry, economics and sociology professions.

As regards policy remedies, the mainstream analysis based on normal accident theory suggests that regulators should break up the big banks so as to create a more competitive financial market. The marxist approach argues that instead of trying to hold back the concentration and centralization tendencies of capital, the more effective path-one more consonant with the basic path of socialization in historical development-would be to take these trends to their logical conclusion by nationalizing the big banks and putting them under democratic control as public utilities. 


\section{The capitalist state}

In marxist theory, the state as a differentiated institutional sphere within and above society is a key feature of all surplus-producing modes of production (i.e. slavery, feudalism and capitalism). Through its monopoly of the means of violence and its institutionalized mechanisms of control such as the legal system, the state is an essential mechanism for assuring the dominance of the dominant class. While Marx never elaborated a fully developed theory of the state, his scattered comments were sufficient to inspire a vibrant tradition of marxist state theory beginning with Lenin and running through the present (for an overview see Jessop 1982).

Two complementary ideas characterize the marxist theory of the capitalist state. On the one hand, and most fundamentally, the state in any class-divided society cannot but function as the state of the dominant class. In a capitalist economy, even when legislators are elected under formally democratic procedures and even when civil servants are selected and promoted meritocratically, the state functions as a "collective capitalist" (Offer 1974). Its role is to manage the health of the overall economy and stability of society on behalf of the capitalist class as a whole, and to defend those class interests both against workers' demands and against the "special" interests of competing individual capitalists and fractions of capital. On the other hand, in certain situations, powerful fractions of the capitalist class - based in specific industries or regions - can exert direct influence over the state's decisions. Against liberal-pluralist ideology, marxist theory sees this kind of direct influence via "cooptation" and "capture" not as a corruption of the democratic state's true nature, but as merely another expression of the fundamental class nature of the state in a class-divided, capitalist society. Sometimes specific fractions of capital are able to influence state policy because of their economic power, and sometimes this goes against interest of capital-in-general.

Illustration: The financial class, state deregulation and the 2007-8

financial crisis. Pozner et al. (2010) argue that lack of regulation of the financial sector was not simply due to the hegemony of efficient market theory, but also direct cooptation of the regulatory process. Goldman Sachs illustrates: a revolving door between the executive suite of Goldman Sachs and the US Treasury department was exploited by Henry Fowler, Henry Paulson and Robert Rubin (as well as Jon Corzine going to the US Senate and Stephen Friedman to the National Economic Council and the New York Federal Reserve Bank). The banking industry had so much influence over regulators that the illegal merger of Citibank and Traveler's Group - a merger with clearly violated the Glass-Steagall Act's prohibition of banks conducting both commercial and investment banking-was retroactively made legal by the repeal of Glass-Steagall, 18 months after the fact.

For marxists, the recurrence of such events is entirely predictable, rather than representing rare and unexpected aberrations. The domination of the state by the financial fraction of the capitalist class was not only a result of capture by special interests of one industry, but reflected a deeper mutation of capitalism itself toward 
a new financialized regime of accumulation. To see "capture" as the key mechanism here therefore misses the deeper interconnection of the state with the capitalist economy as a whole, and draws us back to the naïvely ideological, pluralist view of the state. Financial interests were able to ensure state policy was shaped in their sectional interests because they have become the most economically powerful fraction of capital in the postfordist era.

\section{Stages of capitalist development}

Marx saw capitalism as historically unprecedented in its dynamism and rate of growth; as a result, marxism devotes considerable attention to the periodization of capitalist development. The central insight is that just as history unfolds in successive modes of production, each of these modes, including capitalism, unfolds in several stages driven by the dialectical interaction of technology, economic, political and cultural factors. Such co-evolution gives rise to a development path in which periods of settlement and stasis are succeeded by periods of massive disruption by technical revolutions or endogenous crises, leading to the reconfiguration of institutions into a new (temporary) settlement.

One of the most influential marxist periodizations differentiates three main phases of capitalism: competitive, monopoly, and finance-dominated (see the work of the Monthly Review school of marxism: Baran and Sweezy 1966; Foster and Magdoff 2009). Another differentiates the competitive, fordist, and postfordist periods (see the work of the Regulationist school: Lipietz 1986; Jessop 1997; Aglietta [1970] 2000). These historical formulations offer advantages over influential ahistorical typologies such as the varieties of capitalism approach, because they allow us to specify common growth trajectories across distinct social formations (Vidal 2014), for example the distinction between liberal fordism, blocked fordism and nonliberal fordism (Vidal, forthcoming \#895, see also Lipietz 1987; Peck and Tickell 2000).

Illustration: The subordination of production to finance in the postfordist accumulation regime and the 2007-8 financial crisis. In their analyses of the 2007-8 financial crisis, both Fligstein and Goldstein $(2010: 35,50)$ and Pozner and colleagues (2010) focus entirely on developments within the mortgage securitization market leading to the growth of the subprime market. Pozner et al. emphasize how three acts of deregulation by the US government in the 1980s cleared the way for subprime mortgage lending. Fligstein and Goldstein (2010: 35, 50 , emphasis added) argue that "the demise of the savings and loan banks was a fortuitous collapse that hastened the growth of the MBS market." They conclude that "the proximate cause of the crisis can be found in two shifts in the structure of the mortgage securitization field." First, easy credit allowed banks and other financial institutions to borrow at low interest rates and buy high-yield mortgage-backed securities. Second, when the market for prime mortgages dried up in 2004, this led to predatory lending in the subprime market to continue driving the bubble.

These analyses suggest that the crisis was a contingent outcome of mid-term institutional changes: they do not attempt to push the causal chain back from the 
proximate to the underlying causes. In contrast, the marxist theory of accumulation regimes holds that the economy goes through regular periods of growth followed by crisis, at which point organizations and institutions enter a period of reconfiguration. More specifically, marxism allows us to link the proximate causes of the crisis to longer-term the dynamics of capitalist development, in particular as these dynamics remake the relation between the productive and financial sectors of the economy.

From the Second World War until the early 1970s, the US accumulation regime was fordist: a manufacturing based economy with a class compromise realized through collective bargaining and a Keynesian welfare state (Aglietta [1970] 2000), oligopolistic competition between vertically integrated firms with internal labour markets (Vidal forthcoming) and an investment-production nexus in which finance primarily served the productive sectors (Boyer 2000). As this regime matured in the late 1960s, the fordist model exhausted its ability to generate sufficiently rapid productivity growth, and the economy accumulated excess productive capacity. The capital/labour ratio began to increase, as did the costs of maintaining the post-World-War Two class compromise, and the profit rate declined. In response, corporate America abandoned the class compromise and began an assault on labour to recover profits out of wages (Vidal 2013). Faced with overcapacity, corporate America sought profits from financial circuits rather than productive activities (Krippner 2005). A postfordist, financialized accumulation regime emerged, where financial ideologies dominated corporate governance and where production was subordinated to financial concerns (Lazonick and O'Sullivan 2000; Davis 2009).

Such a marxist analysis suggests that crisis was a largely predictable outcome of a financialized accumulation regime in which there is a surplus of financial capital combined with overcapacity in the productive economy and restricted consumption power due to stagnating wages (partially offset by debt financing). Whereas Fligstein and Goldstein (2010: 46) see the move into the subprime market as a response of originators to a "supply shock" due to saturation of the prime market and the end of easy credit, the marxist account makes saturation and easy credit endogenous. To be sure, Fligstein and Goldstein provide a compelling mid-range examination, but their argument becomes much more compelling if it is complemented by the longer-term marxist analysis.

\section{Conclusion}

We have argued that increasing attention to the critical societal problems of our times by organization studies - and by the social sciences more broadly - points to an urgent need for greater historical depth, interdisciplinarity and a renewed emphasis on grand theory. Deeper historical analysis is necessary to understand better the interrelation of structural and conjunctural sources of contemporary events and social problems, to connect proximate and longer-term causes, and to differentiate cycles from secular trends. Interdisciplinarity is required if we are to 
make better sense of these complex, interrelated dynamics. Grand theory is required to bring sufficient coherence and shared understanding to such complex research undertakings. Building on Lakatos (1980), we have argued that grand theoretical research programs are scientifically progressive when they develop through engagement with middle-range theories that solve empirical puzzles while they systematically defend and revise core assumptions and propositions in a way that expands and enriches the overarching theory.

We have sought to demonstrate that marxist grand theory is a vibrant, progressive research program whose core propositions have received extensive empirical corroboration and theoretical development. The unifying framework of a marxist theory and its core concepts offer much that can enrich other approaches to be found in organization theory.

We showed how the articles in this Special Forum illustrate the fruitfulness of marxist concepts, and we further illustrated our argument using the case of the 2007-8 financial crisis. Organization theorists have to date offered valuable explanations of some of the key features of this crisis. These analyses have emphasized now-classical tropes of organization theory: institutional isomorphism, network effects, institutional logics, complexity, coupling, cooptation. These analyses also reveal the importance of forces and processes that are central to marxist theory: the concentration and centralization of capital within the financial sector, subordination of production to finance in the postfordist accumulation regime, and financial deregulation by a state dominated by financial interests. Yet, mainstream organizational analysis of the crisis has remained largely limited to the three decades leading up to the crisis. A non-expert reading these analyses would be left with a distinct - and, we argue, incorrect - impression that the 2007-8 financial crisis had nothing to do with the structural dynamics of capitalism and everything to do with a contingent set of mid-term institutional, cultural and political forces.

Organization studies will wither if we do not find the conceptual resources with which to address urgent societal problems of our times. As illustrated by our brief case study of the latest financial crisis and in greater detail by the four articles in this Forum, marxist grand theorizing can play a crucial role in energizing and equipping organization studies to meet this challenge. 


\section{References}

Adler, P.S.

2009a "Introduction: A Social Science Which Forgets its Founders is Lost" in The Oxford Handbook of Sociology and Organization Studies. P. Adler (ed), 4-19. Oxford: Oxford University Press.

Adler, Paul S and Bryan Borys

1989 "Automation and skill: Three generations of research on the NC case". Politics \& Society 17/3: 377-402.

Adler, Paul S.

2007 "The future of critical management studies: A paleo-Marxist critique of labour process theory". Organization Studies 28/9: 1313-1345.

Adler, Paul S.

2009b "Marx and organization studies today" in The Oxford Handbook of Sociology and Organization Studies: Classical Foundations. P. S. Adler (ed), 62-91. New York: Oxford University Press.

Aglietta, Michel

[1970] 2000 A Theory of Capitalist Regulation: The U.S. Experience. London: Verso.

Althusser, Louis

2001 "Ideology and Ideological State Apparatus" in Lenin and Philosophy and other essays. L. Althusser (ed), New York: Monthly Review Press.

Augier, Mie, James G. March, and Bilian Ni Sullivan

2005 "Notes on the Evolution of a Research Community: Organization Studies in Anglophone North America, 1945-2000." Pp. 85-95 in Organization Science: A Journal of the Institute of Management Sciences, vol. 16: INFORMS: Institute for Operations Research.

Baran, Paul and Paul Sweezy

1966 Monopoly Capital: An Essay on the American Economic and Social Order: Monthly Review Press. 
Biagioli, Mario

2009 "Postdisciplinary liaisons: science studies and the humanities". Critical Inquiry 35/: 816-33.

Boudon, Raymond

1991 "What Middle-Range Theories Are". Contemporary Sociology 20/4: 519-522.

Boyer, Robert

2000 "Is a Finance-led growth regime a viable alternative to Fordism? A preliminary analysis". Economy and Society 29/1: 111-145.

Braverman, Harry

1974 Labor and Monopoly Capital: The Degradation of Work in the Twentieth Century. New York: Monthly Review.

Brenner, Robert

1976 "Agrarian Class Structure and Economic Development in Pre-Industrial Europe". Past and Present 70/: 30-75.

Brewer, John

2013 The Public Value of the Social Sciences. London: Bloomsbury.

Callinicos, Alex

1991 Against Postmodernism: A Marxist Critique. Cambridge: Polity Press.

Callinicos, Alex

2009a Imperialism and Global Political Economy. Cambridge, UK: Polity.

Callinicos, Alex

2009b Making History: Agency, Structure, and Change in Social Theory. Chicago: Haymarket.

Cohen, AJ and GC Harcourt 
2003 "Retrospectives: whatever happened to the Cambridge capital theory controversies?". The Journal of Economic Perspectives 17/1: 199-214.

Cohen, G. A.

1978a Karl Marx's Theory of History: A Defense. Princeton: Princeton University Press.

Cohen, G.A.

1978b Karl Marx's Theory of History: A Defence. Princeton: Princeton University Press.

Davis, Gerald F.

2009 Managed by the Markets: How Finance Re-Shaped America. Oxford: Oxford University Press.

Delbridge, Rick

2014 "Promising Futures: CMS, Post-Disciplinarity, and the New Public Social Science". Journal of Management Studies 51/1: 95-117.

Delbridge, Rick

2007 "Explaining conflicted collaboration: A critical realist approach to hegemony". Organization Studies 28/9: 1347-1357.

Delbridge, Rick and Tim Edwards

2013 "Inhabiting institutions: Critical realist refinements to understanding institutional complexity and change". Organization Studies 34/ 7: 927-947.

Delbridge, Rick, Marco Hauptmeier, and Sukanya Sengupta

2011 "Beyond the enterprise: Broadening the horizons of International HRM". Human Relations 64/4: 483-505.

Duménil, Gérard and Dominique Lévy

2004 Capital Resurgent: Roots of the Neoliberal Crisis. Cambridge, MA: Harvard University Press. 
Engels, F.

2010 "Letter to C. Schmidt, 27 October 1890" in Marx Engels Collected Works57-65. vol. 49: Lawrence \& Wishart, Electric Book.

Fligstein, Neil and Adam Goldstein

2010 "The Anatomy of the Mortgage Securitization Crisis" in Markets on Trial: The Economic Sociology of the US Financial Crisis. M. Lounsbury and P. M. Hirsch (eds), 27-58. Emerald: Bingley, UK.

Foster, John Bellamy

1999 "Marx's Theory of Metabolic Rift: Classical Foundations for Environmental Sociology". The American Journal of Sociology 105/2: 366-405.

Foster, John Bellamy, Brett Clark, and Richard York

2011 The Ecological Rift: Capitalism's War on the Earth. New York: Monthly Review Press.

Foster, John Bellamy and Fred Magdoff

2009 The Great Financial Crisis: Causes and Consequences. New York: Monthly Review Press.

Gimenez, Martha E.

2001 "Marxism, and Class, Gender, and Race: Rethinking the Trilogy". Race, Gender \& Class 8/2: 23-33.

Glyn, Andrew, Alan Hughs, Alain Lipietz, and Ajit Singh

2007 "The Rise and Fall of the Golden Age" in The Golden Age of Capitalism: Reinterpreting the Postwar Experience. S. A. Marglin and J. B. Schor (eds), Oxford: Clarendon Press.

Gramsci, Antonio

[1929-1935] 1999 Selections From the Prison Notebooks. Translated by Q. Hoare and G. N. Smith. New York: International Publishers.

Guillén, Mauro F. and Sandra L. Suárez 
2010 "The Global Crisis of 2007-2009: Markets, Politics, and Organizations" in Markets on Trial: The Economic Sociology of the US Financial Crisis. M. Lounsbury and P. M. Hirsch (eds), 255-277. Bingley, UK: Emerald.

Hartmann, Heidi I.

1979 "The Unhappy Marriage of Marxism and Feminism: Towards a More Progressive Union". Capital \& Class 3/: 1-33.

Harvey, D.

1990 The Condition of Postmodernity: An Enquiry into the Origins of Cultural Change. Oxford: Basil Blackwell.

Harvey, David

2010 The Enigma of Capital and the Crises of Capitalism. London: Profile Books.

Helleiner, Eric

1994 States and the Reemergence of Global Finance: From Bretton Woods to th e1990s. Ithaca: Cornell University Press.

Jameson, Fredric

1984 "Postmodernism, or the cultural logic of late capitalism". Studies 29/: 54.

Jessop, Bob

1982 The Capitalist State: Marxist Theories and Methods. Oxford: Martin Robertson.

Jessop, Bob

1997 "Twenty Years of the (Parisian) Regulation Approach: The Paradox of Success and Failure at Home and Abroad". New Political Economy 2/3: 503-526.

Jessop, Bob and Ngai-Ling Sum

2001 "Pre-disciplinary and Post-disciplinary Perspectives". New Political Economy 6/1: 89-101.

Klein, Naomi 
2014 This Changes Everything: Capitalism vs. the Climate. New York: Simon \& Schuster.

Kliman, Andrew

2012 The Failure of Capitalist Production: Underlying Causes of the Great Recession. London: Pluto Press.

Krippner, Greta R.

2005 "The Financialization of the American Economy". Socio-Economic Review 3/173-208.

Lakatos, Imre

1980 The Methodology of Scientific Research Programmes. Cambridge: Cambridge University Press.

Lazonick, William and Mary O'Sullivan

2000 "Maximizing shareholder value: a new ideology for corporate governance". Economy and Society 29/1: 13-35.

Lipietz, Alain

1986 "Behind the Crisis: The Exhaustion of a Regime of Accumulation. A 'regulation school' perspective on some French empirical works". Review of Radical Political Economics 12/1\&2: 13-32.

Lipietz, Alain

1987 Mirages and Miracles: Crisis in Global Fordism. London: Verso.

Lukacs, G.

1971 History and Class Consciousness. London: Merlin.

Lyotard, Jean-Francois

1984 The Postmodern Condition: A Report on Knowledge. Manchester: Manchester University Press. 
MacKenzie, Donald A. and Judy Wajcman

1999 The social shaping of technology. Buckingham England; Philadelphia: Open University Press.

Martin, B.

1976 "Review of Perry Anderson, "Passages from Antiquity to Feudalism" and "Lineages of the Absolutist State". ". British Journal of Sociology 27/2: 267271.

Marx, Karl

[1867] 1990 Capital, Vol. 1. Translated by B. Fowkes. London: Penguin.

Marx, Karl

[1894] 1981 Capital, Vol. 3. London: Penguin.

Marx, Karl and Frederick Engels

[1846] 1996 The German Ideology. New York: International Publishers.

Merton, Robert King

1968 Social theory and social structure. New York,: Free Press.

Negri, Antonio

1989 Marx beyond Marx: Autonomedia.

Peck, Jamie and Adam Tickell

2000 "Searching for a New Institutional Fix: the After-Fordist Crisis and the GlobalLocal Disorder" in Post-Fordism: A Reader. A. Amin (ed), Oxford: Blackwell.

Perrow, Charles

1984 Normal accidents : living with high-risk technologies. New York: Basic Books.

Perrow, Charles 
2010 "The meltdown was not an accident" in Markets on Trial: The Economic Sociology of the US Financial Crisis. M. Lounsbury and P. M. Hirsch (eds), 309330. New York: Emerald.

Polanyi, Karl

[1944] 1968 The Great Transformation: The Political and Economic Origins of Our Time. Boston: Beacon Press.

Pozner, Jo-Ellen, Mary Kate Stimmler, and Paul M. Hirsch

2010 "Terminal Isomorphismand the Self-Destructive Potential of Success: Lessons from Subprime Mortgage Origination and Securitization" in Markets on Trial: The Economic Sociology of the US Financial Crisis. M. Lounsbury and P. M. Hirsch (eds), 181-214. Bingley, UK: Emerald.

Runciman, W. G.

2007 "Introduction" in Marxist History-Writing for the Twenty-First Century. C. Wickham (ed), 1-14. London: Oxford Univerity Press/British Academy.

Samuelson, Paul A

1966 "A summing up". The quarterly journal of economics: 568-583.

Sayer, Andrew

2001 "For postdisciplinary studies: sociology and the curse of disciplinary parochialism/imperialism" in For Sociology: Legacies and Prospects. J. Eldridge, J. MacInnes, S. Scott, C. Warhurst, and A. Witz (eds), 83-91. Durham, UK: Sociology Press.

Shaikh, Anwar

1982 "Neo-Ricardian Economics: A Weatlh of Algebra, a Poverty of Theory". Review of Radical Political Economics 14/2: 67-83.

Shaikh, Anwar M and E Ahmet Tonak

1997 "Measuring the wealth of nations". Cambridge Books.

Smith, Chris and Peter Meiksins 
1995 "System, society and dominance effects in cross-national organisational analysis". Work, Employment \& Society 9/2: 241-267.

Stark, David. 2000. "For a Sociology of Worth." Working Paper Series, Center on Organizational Innovation, Columbia University.

Vidal, Matt

2013 "Postfordism as a dysfunctional accumulation regime: a comparative analysis of the USA, the UK and Germany". Work, Employment \& Society 27/3: 451471.

Vidal, Matt

2014 "Incoherence and Dysfunctionality in the Institutional Regulation of Capitalism" in Comparative Political Economy of Work. M. Hauptmeier and M. Vidal (eds), 73-97. Basingstoke: Palgrave Macmillan.

Vidal, Matt

forthcoming "Industrialization, Fordism and the Golden Age of Atlantic Capitalism " in Sage Handbook of the Sociology of Work and Employment. S. Edgell, $\mathrm{H}$. Gottfried, and E. Granter (eds), London: Sage.

Vidal, Matt and Jamie Peck

2012 "Sociological Institutionalism and the Socially Constructed Economy" in The Wiley-Blackwell Companion to Economic Geography. T. Barnes, J. Peck, and E. Sheppard (eds), 594-611. Oxford: Wiley-Blackwell.

Wallerstein, Immanuel

1979 The Capitalist World-Economy. Cambridge, UK: Cambridge University Press.

Wickham, Chris

2007 "Marxist History-Writing for the Twenty-First Century." Oxford: The British Academy/Oxford University Press.

Wood, Ellen Meiksins

2003 Empire of Capital. London: Verso. 
Wright, Erik Olin

1978 Class, Crisis, and the State. London: Verso.

Wright, Erik Olin

1997 Class Counts: Comparative Studies in Class Analysis. Cambridge: Cambridge University Press. 